\title{
Strategy Cultural Resources Chinese Version of "Soft Power"
}

\section{Marina Fomina}

\author{
Olga Borisenko
}

Transbaikal state university, Russia, Chita

\author{
Doi:10.5901/mjss.2015.v6n5s3p184
}

\begin{abstract}
The article analyzes the policy of "soft power" in China. The authors shows that the policy of "soft power" has a humanitarian content. Cultural resources of the state directs the policy of "soft power" and its strategy. The strategy of "soft power" is realized through the research centers and institutes. Cultural resource embodied in the national idea. China is committed through a policy of "soft power" to exercise their traditional values. China and Russia implementation of the policy of "soft power" - the degree of influence in the international arena.
\end{abstract}

Keywords: Russia, China, the strategy of cultural policy, the concept of "soft power", a cultural resource.

\section{Introduction}

As in the Address to the Federal Assembly in December 2013, and in 2014, Russian President Vladimir Putin said that Russia increased level of responsibility in the world, as a key center of influence, which is actively involved in the formation of a new polycentric international system in addressing key global and regional problems. This was another fact that confirms the need not only for the formation of mechanisms and instruments of Russia's "soft power", which is now in the international arena increasingly represented Rossotrudnichestva activity as analogue US Agency for International Development (USAID), and the Russian Union of Youth but also the need of understanding, organizing and specifying the forms and directions of their activity at the level of interdisciplinary research.

"Soft Power" includes not only political institutions, but also the cultural values and consumer preferences, which means limiting specification values images. In other words, the image of the country, which is a projection of "soft power" - should be visible (Rodkin, 2014). It is worth noting that in the first place, a distinctive point is the absence of coercion. No one is forcing to take the culture of another country, it is not imposed on you. Yet Joseph Nye, said that "deception is almost always more effective than coercion"(Nye, 2004).

\section{Methodology}

If we analyzing the concept of "soft power" (taking into account the development of its civilization stages), we can define the following points. Ideologist of "soft power" J. Nye (Nye, 2004), the concept of justified as a foreign policy strategy aimed at maintaining a positive image of the country, which is achieved through the voluntary support of allies. In his opinion, contribute to this: the attractiveness of culture, political ideals and foreign diplomacy, which is positioned in the international arena. But here it is worth noting that the political representation of the effect of culture - is not new to us, as it is has enabled the world to learn and understand the "Russian soul", "the Orthodox faith" and "Russian character". How very clearly, in our opinion, noted this effect Chinese counterpart, soft power "is the wisdom and strategy of the state" (Tszaytsi, 2009).

"Soft power" - is not political rhetoric, but a means to improve global competitiveness. Because of economic, intellectual and communication competition, not war (which is the lot of the underdeveloped countries and societies) became the main means of achieving victory in the XXI century (Rodkin, 2014). The dialogue of cultures is a complicated process, because not all elements of another culture can be intelligible. For example, to take certain national peculiarities of another culture, it is necessary insight into its values, traditions and outlook. Although the culture of mutual understanding that has developed through the centuries, and allowed the man to provide "complex unity of all mankind", all human cultures, there is no single world culture, but there is a "complex unity of all mankind" (Koksharov, 2003), and this manifests the humanistic principle. 


\section{Discussion}

Technology "soft power" of European countries (the Nobel Prize, the European market, public diplomacy, the Bologna process and others) has always been competitive ability. It is no coincidence that it is the English language (the English version, not American English) is an interstate language of communication, business contacts; European art, literature, music enjoyed international recognition, and European fashion designers dictate not only the style of fashion, but also a lifestyle for women around the world.

For Russian policy concept of "soft power" has become customary in recent years, associated to a greater extent, with the manifestation of the implementation of both internal and foreign policy of China.

China, like Russia, produces a "soft power" in their understanding of how the wealth of culture, history, the state power. This quality distinguishes Chinese "soft power" (as well as Russian) on USA soft power, in which it grows from the individuals from the private sector, civil society. Integral and important instruments of "soft power" of China are promoting traditional Chinese culture, which is based on the ideas of Confucianism, and promotion of Chinese language. These effective tools for the implementation of "soft power" are an information resource with which the Chinese government creates a positive image of the country, not only globally, but also in terms of cross-border socio-cultural space.

Considering the instruments of "soft power," Chinese experts attributed to him, and regional integration, which makes China and powerful regional leader with cultural potential, with more than 5000 years. International bilateral and multilateral cooperation is an effective instrument of foreign policy of the state, providing cultural and information presence of Chinese civilization abroad and the creation of its positive image in other countries.

China is not only a country of ancient civilization, but also the country, looking to the future, and it is associated with the modernization of Chinese society, the reform and improvement of the social relations, cultural, political and economic structures, etc. Reform of course, carried out in the context of globalization. China understands that it is necessary to keep pace with the times and therefore it is necessary to form a trans-social life in such a way as to meet the new realities, and preserved the traditions of Chinese, Chinese culture and Chinese mentality. In other words, the Chinese are in a globalized world want to preserve their national identity, and they succeed.

Of particular context analysis of the factors and areas of translation and consolidation of Chinese culture in the border areas of Russia attaches their implementation under the guidance of the policy implemented by the Chinese "soft power". Analysis of the work of both Russian and Chinese authors, suggests that elements of culture as measurable objects become real tools of Chinese "soft power".

In ideological terms, China does not have such an attractive "American Dream" as the United States. And Beijing is well aware. On this basis, the basic rate in promoting China's "soft power" China is on a gradual change, or at least reduce the negative image of the "Celestial Empire" in the eyes of the neighbors. To do this through the Confucius Institute opened new directions initiated various programs to train students in China, the passage of teachers training and much more

And here it is worth noting that the characteristic direction of the organization of research on emerging issues in global politics in China is embodied in systems research institutes and centers. For example, issues of the (programming and forecasting) of the Shanghai Cooperation Organization (SCO) today presented the world's largest number of specialized research organizations. These include: Chinese Research Center of the SCO, SCO Research Center at the Chinese Academy of Science, Department of Research of the SCO in the study of China Institute of International Affairs, Scientific Research Center of Fudan University, Shanghai Cooperation Organization, SCO Research Center studies the Shanghai Academy of Science, Scientific Research Institute of East China SCO Pedagogical University and the China Development Bank, Institute for Public Diplomacy Research SCO Shanghai University, and many others (Zhang, 2014).

We can assume that China is ahead of the countries of Western Europe and the USA in the number and diversity of an extensive system of scientific structures, dedicated to research in Russia: Science Center of Northeast Asia Heilongjiang University, Harbin; Science Center of Northeast Asia, Jilin Province, Changchun, Jilin Province; Russian Research Institute of problems in Eastern Europe and Central Asia, China Academy of Social Sciences, Beijing; Science Center at Russian Diplomatic Academy, Beijing; Science Center of Northeast Asia, Beijing; Scientific Research Institute, Russian Academy of Sciences in social Jilin Province, Changchun, Jilin Province; Russian Scientific Research Institute Heyheskogo Institute, Heihe; Science Center at the Russian Academy of Sciences, Social City, Liaoning Province. Ayshan city. And this is only a few institutes and centers, mostly located in the Northeast of China.

Handling party leaders of China to the "soft power" was first announced in October 2007 at the XVII Congress of the Party, which identified the main directions of its formation: 1) create a system of "core socialist values" to increase "attractive and cementing force of socialist ideology"; 2) to form a "harmonious culture, nurture civilized manners"; 3) distribution of "national culture, to build a common spiritual center of the Chinese nation"; 4) to promote "innovation in 
culture, enhance the vitality" of its development (Tszaytsi, 2009).

In 2006, at the November Eighth National Conference of representatives of literature and art in the speech of the party leader, Hu Jintao, according to Mr. Liu Tszaytsi, it was noted that "in the face of the great currents, which merge different ideas and culture", "in the face of diversity and revitalizing the cultural life of society "China will solve the problem -" how to precisely target the development of culture "," to create a new brilliant pages of the national culture, to increase the international competitiveness of culture "and" increase the soft power of the state "( Tszaytsi, 2009).

This setting has been directed to ensure that in the development of national culture, to enhance the role of Chinese culture in the international arena, and cultural products - on the world market. Thus, as noted by O. Borokh and A. Lomanov that the Communist Party of appeal to the American concept of "soft power" indicates the ability of "the Chinese leadership to absorb foreign ideas useful" (Borokh, Lomanov 2012). It's not just about the "capacity to absorb", and, to a greater extent on the ability to build a strategy that reflects the concept of Deng Xiaoping, the meaning of which is to wait for their time and develop their potential.

And, like any political targets set at the state level, this problem was not only a scientific basis (through the concept of social harmony), but also institutional support. We see this in the organization of scientific research "soft power" supported by the Ministry of Education of China, determined, as noted by Liu Tszaytsi, financial support for the implementation of the "Research building" soft power "and the development strategy of China» "(Tszaytsi, 2009) defined programs of the State Research Center of "soft power" in the field of culture at the Institute of International Relations, Peking University. According to the Chinese Minister of Culture Cai Wu Centre will not only spread the Chinese to raise the value and national image, as will ensure the "Chinese Dream", as it is Culture is a key strategic area for China. Problems of "soft power" is also dedicated to the work of Chinese scientists and Wang Jianjun, Yang Tszemyan, Sintyan Yu, Liu Tszaytsi and other.

Worth noting that in the context of general information about the Chinese "soft power", talking about the Russian version - only planned. Today Russia has no such analogs, no large-scale projects that would be relevant to the national culture would be as dominant, a key phenomenon, not only in our, but also in space. On the other hand, as is authorized to use this concept ("soft power") applicable to our culture, mentality and psychology? How it will be filled with meaningful as it would relate to the sense that it is peculiar?

In the context of the above, you can see that at the level of political dialogue, journalistic articles the concept of Russian instruments of "soft power" has become not only emerge but also be discussed. But, nevertheless, it is necessary to declare that the time for its comprehensive study "came yesterday." It is caused by the fact that since 2012 (when Putin drew attention to it public), the Russian implementation instruments of "soft power" - the object of attention not only to the political community, but also research, because they have become an alternative factor of international influence.

Today, Russian studies of "soft power" are presented in the context of global challenges (Chumakov, 2014), national security and foreign policy of Russia (Tszaytsi, 2009), and others. In the context of the regional Russian-Chinese relations semantic dominant of this concept, first of all, determined, namely, cultural factors, which serve tools of "soft power" (Abramov, Shufang, 2011). Therefore, analysis of the works of both Russian and Chinese authors, suggests that elements of culture as measurable objects become real tools of Chinese "soft power" (Morozova, 2010).

But against the background of research, individual publications, dissertations, even in Russia there is no single center, like the Chinese. As noted in one of his speeches President Putin, Russia is only beginning to realize that the national interests and national security concerns have quite a powerful factor in the positioning state interests abroad are instruments of "soft power." No recognition of this fact has led to earlier that Russia today has about 60 scientific and cultural centers abroad, and China, in turn - around 1000. To this day, the program of work with compatriots, the SCO University, cultural diplomacy, etc. operates adequately positioning tasks Russia abroad in general and, in particular, in the PRC. Head of the Center of Political Analysis P. Danilov (Borisov, 2014) notes that the Russian soft power tools and even "young", however, also have a degree of influence and demand in the international space. But if you think the incidence, then, according to analysts, it is - not only external, but also internal vector, which should be aimed at debunking "black myth" about Russia.

And if in the European space, as noted in an interview with Foreign Minister Sergei Lavrov (Lavrov, 2013), the Russian policy of "soft power" itself, albeit belatedly, adopted through a set of different tools (the fund "Russian World" TV channel Russia Today, mobility programs leading universities, Rossotrudnichestvo program, etc.), then to the north-east Asian region is more than the positioning of Russia in the framework of regional (Far East, Amur, Trans-Baikal, etc.) cooperation.

At the regional level of the Russian-Chinese cooperation with the realization of how Chinese and Russian side instruments of "soft power" is a measure of openness of the state, one of the results of modernization, the motion vector 
of intercultural interaction to the cultural and political dialogue. Every year Russia further strengthens the status of an international player, who moved from the category of "hard power" to "soft power", that Chinese partners has become a criterion in the politics of international relations.

It is of scientific interest "Analytical Report" Parshin PB, in which the author identifies the main indicators of "soft power" in Russia, and not only the degree of implementation but also recognition in the international arena (Parshin, 2013). So of the 13 indicators in the Russian parameters "soft power" is just the historical heritage in the world of highlevel perception. With regard to culture Parshin PB It gives a double feature, which allows you to treat it as a high - elite culture (but the demand for it abroad only at selected) and how uncompetitive - popular culture (with the rare exception of those names that enjoy recognition abroad). Therefore, a deliberate policy of the state should define a strategy that would allow this balance. As noted in the summer of 2014 Volodin (Volodin, 2014) at the level of the government is preparing the project "On the comprehensive strategy to expand the humanitarian impact of the Russian Federation in the world," which, according to experts, is to regulate the Russian policy of "soft power."

\section{Conclusion}

If you focus on China's experience we can say that the "soft power" is a two-level. The first - the internal, which is implemented through the formulation of a national idea. The second - external, which reveals and substantiates the position in the international arena. If the first level of "soft power" (both in Russia and in China), aimed at creating a strategy, in the second - to create the image. On whatever form of "soft power" (European or American, Chinese or Indian), we would not be talking - the emphasis will be on the humanitarian value, ideological, mental part of it.

\section{Acknowledgment}

Article made under a grant for state support of young Russian scientists $(\mathrm{PhD})$ of the Council for Grants of the President of the Russian Federation MK - 3682.2015.6.

\section{References}

Abramov, V.A. and Shufang Yan (2011) Cultural industries as a mechanism for the implementation of the value potential of "soft power" of China // Bulletin of the Trans-Baikal State University. №. 7

Borisov, A. The experts discussed the "soft power of Russia." Website: Rossiyskaya Gazeta from: http://www.rg.ru/2014/10/31/silasite.html

Borokh O. (2012) A. Lomanov From the "soft power" to "cultural power" / Russia in Global Affairs. No. 4 (electron. Resource) from http://www.globalaffairs. ru/number/Ot-myagkoi-sily-k-kulturnomu-moguschestvu-15643.

Chumakov (2014) "Soft power" as a way of solving problems in a global world // Age of Globalization. №. 2. pp 192-195.

Joseph, S. Nye (2004) Soft Power: The Means To Success In World Politics. - New York: Public Affairs. pp. 191.

Koksharov, N.V. (2003) Interaction of Cultures: Dialogue of Cultures // theoretical journal «Credo new». № 3. pp.14.

Lavrov, S. We started to develop instruments of "soft power" after their inventors. Website: Russian Council on International Affairs from: http://russiancouncil.ru/inner/?id_4=2878\#top

Liu, Tszaytsi (2009) "Soft power" in the development strategy of China // Polis. No. 4. pp. 118 -121.

Morozova, V.S. (2010) Russia and China: intercultural interaction in the context of the transformation of regional culture (for example, the Trans-Baikal Territory) // Problems of the Far East. №. 2. pp. 135-140.

Parshin, P.B. (2013) The issue of "soft power" in Russian foreign policy: Analytical Report. Issue 1 (36). - M .: Publishing House of the Moscow State Institute. pp. 40.

Rodkin, P. "Soft power" - is Russia ready to battle the world "windows"? from http://mn.ru/oped/20130129/336429595.html

Volodin, A. Russia and "soft power": website of the Russian trends URL http://rostend.su/node/1859

Zhang, F. (2014) Thinking about studies the Shanghai Cooperation Organization in China // scientific, educational and cultural cooperation between the SCO member states: HP Intern. scientific and practical. Conf .: in 2 h. - Part 1. - Read ZabGU. pp.113117. 